\title{
Hunter-gatherer mobility and territories in the dunefields of center Argentina
}

\author{
Pablo G. Messineo, María P. Barros \\ INCUAPA-CONICET, Facultad de Ciencias Sociales (UNICEN). Av. Del Valle 5737, Olavarría (7400), Buenos \\ Aires, Argentina. Email: Messineo: pmessine@soc.unicen.edu.ar; Barros: pbarros@soc.unicen.edu.ar
}

\begin{abstract}
:
The distribution of certain rocks in the landscape allows us to reconstruct diverse aspects of past hunter-gatherer behavior. In this work, we evaluate the mobility patterns employed by these groups and the presence or absence of boundaries in the Aeolian system of the center of Argentina. To accomplish this objective, we consider two types of evidence: 1) raw material frequencies and distributions in three areas of this Aeolian System and 2) presence and frequency of knapping stones from Tandilia sources. We construct a fall-off curve that is based on the relationship between the frequency of an item and the distance to the source of supply. The characteristics of each area yielded the human groups that inhabited delineate different modes of exploitation of the rocks. The fall-off curve documents a steep drop-off between 300 and $350 \mathrm{~km}$ from the Tandilia source and the spatial analysis indicates that within this distance the source probably represents the threshold of direct access to the quarries. Tandilia stone-tools seem to systematically supply a relatively wide area of the Central Pampean Dunefields of the Pampa grasslands, through varied processes, but they arrive at very low frequencies over great distances. The presence of Tandilia rocks in the Western Pampean Dunefields and Western Pampas Sand Mantles and Dunefields indicates social interaction between human groups that shared some common technological knowledge. The presence of stones in the Central Pampean Dunefields coming from the xerophytic woodland of the Dry Pampas can be related with contacts and exchanges among the hunter-gatherer group that occupied different territories.
\end{abstract}

Keywords: aeolian landscape; stone transport; hunter-gatherers; mobility patterns; human interactions; orthoquartzite; chert; Holocene

\section{Introduction}

The identification of lithic source provenance and the geographic space in which the lithic artifacts traveled often is central in the analysis of past hunter-gatherer's mobility and territories (Seeman et al. 2020). The distribution of certain rocks in the landscape, with known provenance, allows us to reconstruct diverse aspects of past hunter-gatherer behavior. By tracing these artifacts to their geological source, it is possible to recognize the location of the lithic acquisition areas, the predominant direction of movement, the mobility pattern, and the territories traveled and occupied by different human groups (Andrefsky 1994; Binford 1979; Kelly 2011; Meltzer 1989; Smith et al. 2012).

Published by the School of History, Classics and Archaeology, University of Edinburgh ISSN: 2055-0472. URL: http://journals.ed.ac.uk/lithicstudies/

Except where otherwise noted, this work is licensed under a CC BY 4.0 licence. 
In addition, the quantity and types of lithic materials conveyanced, the distances traveled and the degree of tool transformation make it possible to define a technical behavior linked to the lithic supply patterns and the objective of productions (Féblot-Augustins 1997: 21-25). These factors allow determining the cases that should be considered as direct access to resources, which allude to the size of the territory or foraging range that a human group habitually occupied, and which are associated to social interaction among hunter-gatherer societies (Bamforth 1986, 1990; Hughes 2011: 7-9; Kuhn 1995: 18-37; Mangado 2006; Pallo \& Borrero 2015; Seeman et al. 2020).

Considering these issues, the main objectives of this work were to evaluate the mobility patterns employed by hunter-gatherer groups and to identify the presence or absence of possible territories in three areas in the Aeolian System of the center of Argentina. To accomplish this objective, we consider raw material frequencies and distributions in the Central Pampean Dunefields, the Western Pampean Dunefields, and the Western Pampas Sand Mantles and Dunefields areas. Likewise, previous studies carried out in the Central Pampean Dunefields of the Pampa grasslands indicate the absence of stone outcrops in this area and in most archaeological sites there is a predominance of tool-stones that come from Tandilia sources (Messineo et al. 2019). Furthermore, these rocks are present in the other two areas, indicating a long-distance move even in places where other raw materials closer to each other have the same or better knapping quality (Berón et al. 2015; Heider 2016a). Taking this information, another objective is to evaluate the geographic space in which the lithic artifact manufactured with stones from Tandilia traveled through this Aeolian system. To evaluate this distribution, we use the presence and frequency of Tandilia tool-stones in those archaeological assemblages corresponding to hunter-gatherer populations that occupied the center of Argentina during the Holocene.

In this study, the provenances of lithic raw materials are used to judge the geographic or territorial scale of population mobility in three areas of the Aeolian system of central Argentina (Zárate \& Tripaldi 2012). We infer the geographic location of the potential territories occupied by hunter-gatherers through the examination of the distribution of toolstones of known origin following fall-off patterns according to its distance to the source (Renfrew 1977). Our expectation is that if there were access to different lithic resources and possibly territory boundaries for human groups we would see spatially discrete lithic areas across the Aeolian system of central Argentina.

\section{Regional setting and lithic sources in the center-east of Argentina}

The central region of Argentina is characterized by one of the most important Aeolian systems, which comprises three main areas: Central Pampean Dunefields (CPD), Western Pampean Dunefields (WPD), and Western Pampas Sand Mantles and Dunefields (WPMD). The CPD covers the western and southwestern part of Buenos Aires, eastern La Pampa, southern Córdoba and southernmost part of Santa Fe provinces (Figure 1). This area mainly consists of linear dunes, 100-130 km long and 2-3 km wide, which present a general N-NE trend associated with parabolic dunes (Malagnino 1989). The dune and aeolian sand sheets in the interdune area produce an irregular relief, 2-5 m high, where the depressions between the sand mounds commonly host temporary or permanent shallow lakes (Zárate \& Tripaldi 2012).

The WPMD is located in the central-eastern of La Pampa province (Figure 1). A remarkable geomorphological feature is the occurrence of a series of large depressions known as transversal valleys (Malagnino 1989) cutting across the structural plain. They are major geoforms, 60-100 km long and 80-100 m deep, with a general NE-SW trend. The dominant aeolian landforms consist of sand mantles covering both the structural plain surface and the peneplain, while dunefields occur along the transversal valleys (Zárate \& Tripaldi 2012). 


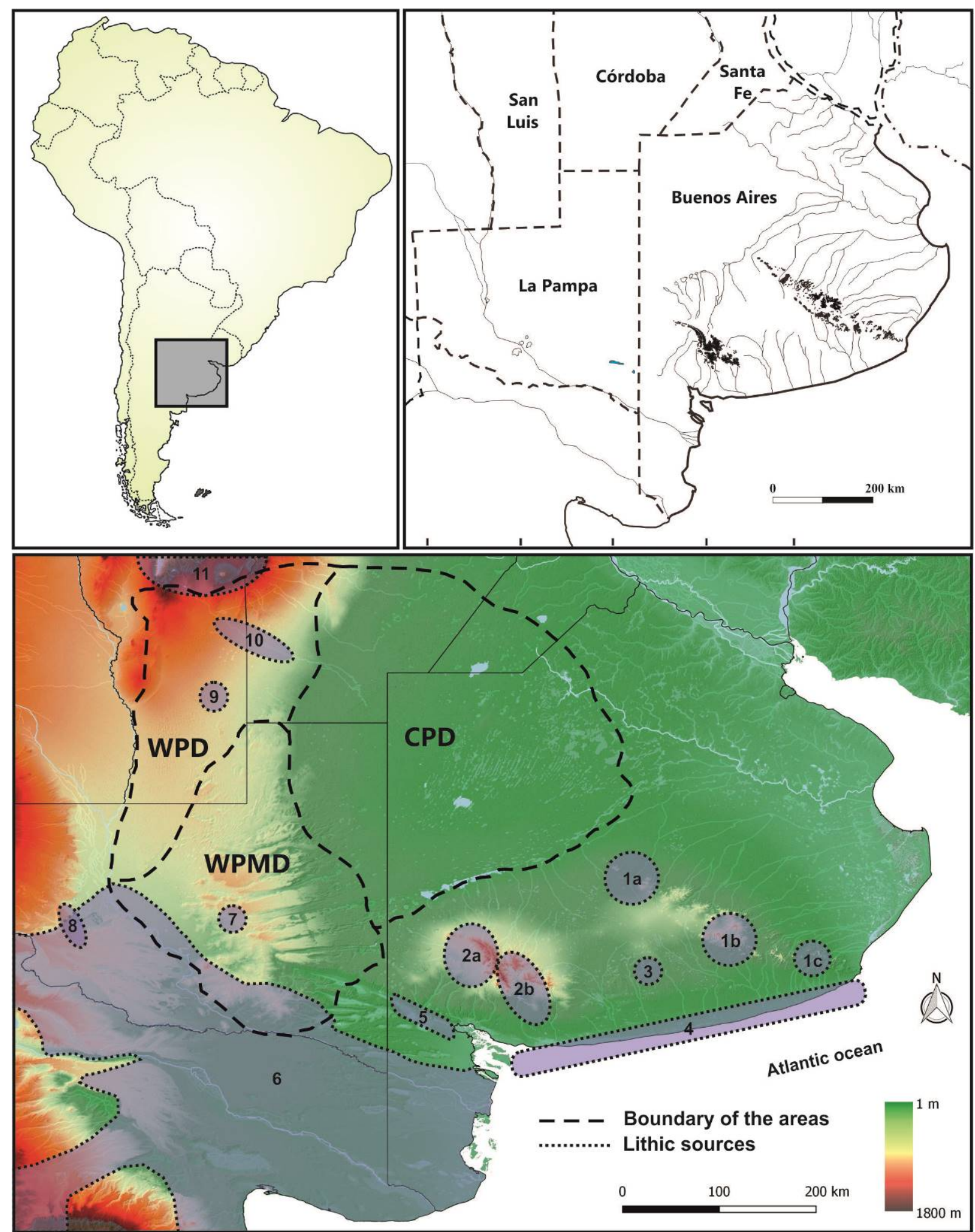

Figure 1. Location of the Aeolian areas and regional base of lithic resources and potential sources of raw material in the center-east of Argentina. CPD. Central Pampean Dunefields; WPD. Western Pampean Dunefields; WPMD. Western Pampas Sand Mantles and Dunefields; 1a. northwestern sector of Tandilia Hill (orthoquarzite of the Sierras Bayas Group and Balcarce Formation, chert from the Cerro Largo Formation, silicified dolomite, quartz, and granites); 1b. central-eastern sector of Tandilia Hill (orthoquarzite from the Sierras Bayas Group, chert, microcrystalline silicates, silicified dolomite, and diabases); 1c. south-eastern sector of Tandilia Hill (orthoquarzite of the Balcarce Formation and quartz); 2a. Ventania Hill (metaquartzite and rhyolite of La Mascota, La Lola, Trocadero and Napostá Formations, orthoquartzite from the Red Conglomerate, 
granites, and chert); 2b. metaquartzite and quartz in secondary deposits in the mountain foothills and in the ancient mouths of the Río Sauce Grande; 3. scantily exposed bedrocks of silicified siltstone in the Interhill plain; 4. coastal pebbles of basalt, ryolithe, quartzite, dacite, chert, and tuff in the Atlantic coast; 5. secondary deposits of cobbles and pebble of Patagonian Shingle Formation in the Chasicó-Salinas Chica basin; 6. secondary deposits of cobbles and pebbles of Patagonian Shingle Formation (basalt, silicified limestone, chalcedony, silex, quartzite, rhyolite, and quartz) in the Salado, Colorado and Negro River basins; 7. silicified limestone in the El Carancho site and Valle de Daza; 8. silicified limestone in the Meseta del Fresco Hill; 9. secondary deposits of chalcedony in Loma de los Pedernales site; 10. secondary deposits of quartz and sandstones in the Quinto River; 11. silex, quartz, quartzite, and chalcedony in the Central Hills.

The WPD area mostly occupies central-southern of San Luis and Córdoba provinces (Figure 1). It is limited by the Desaguadero-Salado-Curacó fluvial system and some low hills westward and by the southern distal piedmont of the San Luis ranges to the north. This region is characterized by a low relief plain drained by ephemeral streams and the Quinto River. The WPD area includes diverse dunes surrounded by discontinuous aeolian mantles (Zárate \& Tripaldi 2012).

Studies of raw material procurement, mobility, and exchange in the center-east of Argentina have relied in large measure on the well-studied lithic sources record compiled over the last 25 years or so (e.g., Barros et al. 2015; Berón 2006; Carrera Aizpitarte et al. 2015; Catella et al. 2013; Colombo 2011; Flegenheimer et al. 1996; Heider 2015: 317-322; Messineo \& Barros 2015, among others). Lithic sources in this region are restricted to delimited sectors of the Pampa grasslands, the xerophytic woodland of the Dry Pampas, and the Central Hills of Córdoba and San Luis provinces (Figure 1). In this figure it can be clearly seen that the lithic resources are absent in the CPD (Messineo et al. 2019) while they are scarce, highly localized, and heterogeneously distributed across the WPD and WPMD areas (Berón 2006; Carrera Aizpitarte 2014: 277-299; Carrera Aizpitarte et al. 2015; Heider 2015: 317-322; Heider \& Demichelis 2015; Martínez et al. 2009).

In the Pampa grasslands there are several areas for the acquisition of lithic raw materials that have been used for tool manufacture (Figure $1 \mathrm{~N}^{\mathrm{o}} 1-5$ ). Extensive primary outcrops of fine-grained orthoquartzite from the Sierras Bayas Group, chert from the Cerro Largo Formation and silicified dolomite from the Villa Mónica Formation are located in the northwestern and central-eastern sector of the Tandilia Hill (Figure $1 \mathrm{~N}^{\mathrm{o}} 1 \mathrm{a}$ and $1 \mathrm{~b}$; Colombo 2011; Flegenheimer et al. 1996; Messineo \& Barros 2015). Also, medium-grained orthoquartzite from the Balcarce Formation and quartz can be found in the eastern sector of the Tandilia Hill (Figure $1 \mathrm{~N}^{\mathrm{o}}$ 1c) (Bonnat 2020: 32-33).

Besides, rhyolite, metaquartzite, and orthoquartzites from La Mascota, La Lola, Trocadero and Napostá Formations represent primary and secondary outcrops in the western sector of the Ventania Hill and in the adjacent piedmont. In the lowlands of Chasicó-Salinas Chicas there are remnants of the Patagonian Shingle Formation "Manto Tehuelche" (Figure 1 $\mathrm{N}^{\circ}$ 2a and 5) (Catella 2014: 83-86, 242-244; Catella et al. 2013; Martínez et al. 2009; Oliva \& Moirano 1997; Oliva et al. 2006). In addition, secondary cobbles and pebbles deposits of metaquartzite, sandstones, and quartz are available from the mountain foothills to the ancient mouths of the Río Sauce Grande (Figure 1 N² 2b) (Bayón et al. 2006). In the Interhill Pampas, between Tandilia and Ventania, scantily exposed bedrock of silicified siltstone from the Pillahuinco Group was identified (Figure $1 \mathrm{~N}^{\circ} 3$ ). On the Atlantic coast, there are coastal cobbles and pebbles with diverse lithologies, such as basalt, ryolithe, quartzite, dacite, chert, and tuff (Figure $1 \mathrm{~N}^{\circ} 4$ ) (Bonomo \& Prates 2014).

In the xerophytic woodland of the Dry Pampas (Figure $1 \mathrm{~N}^{0} 6-11$ ), the primary raw material deposits are located in the west sector (silicified limestone of Meseta del Fresco Formation) and in the central-east of La Pampa province such as El Carancho site and the Valle de Daza (Figure $1 \mathrm{~N}^{\circ} 7$ and 8) (Berón 2006; Carrera Aizpitarte et al. 2015; Charlin 2002: 209-210). Secondary deposits of cobbles and pebbles of Patagonian Shingle Formation 
are concentrated in fluvial valleys, such as the Salado, Colorado, and Negro Rivers (Figure 1 $\mathrm{N}^{\circ}$ 6) (Berón 2006; Carrera Aizpitarte \& Berón 2020; Martínez et al., 2009; Santos Valero 2015). Among the knappable materials, there are basalt, chalcedony, silex, and silicified limestone. In addition, in the northern sector of the Dry Pampas, secondary deposit formed by chalcedony and quartz nodules were found at the Lomas de los Pedernales site and the Quinto River (Figure $1 \mathrm{~N}^{\circ} 9$ and 10) (Heider 2015: 317-322; Heider \& Demichelis 2015). Last, the Central Hills region (Figure $1 \mathrm{~N}^{\circ} 11$ ) presents primary and secondary outcrops of silex, quartz, quartzite, and chalcedony (Heider 2015: 317-322).

\section{Materials and methods}

In order to examine long-term trends in mobility and territories, raw materials with identified provenance were selected based on their broad known distributions across the Aeolian systems of central Argentina (Figure 1). The identification of raw material types and sources of stone artifacts in our sample was based on macro and microscopic characteristics gathered from the authors' own research in sites from the CPD in the Pampa grasslands and from an extensive survey of published literature revision of sites from the rest of the areas (e.g., Bayón et al. 1999; Berón 2004: 211-254, 2006; Carrera Aizpitarte 2014: 311-364; Carrera Aizpitarte et al. 2015; Catella 2014: 242-249; Catella et al. 2013; Colombo 2011; Flegenheimer et al. 1996; Heider 2015: 317-322; Heider \& Demichelis 2015; Messineo \& Barros 2015; Oliva \& Moirano 1997, among others). In this paper, we use the terms silex and chert to refer to two types of lithic raw materials that have different macroscopic and microscopic characteristics and correspond to different geological formations. The former are those siliceous rocks formed by secondary deposits of cobbles and pebbles that come mostly from the Patagonian Shingle Formation from the xerophytic woodland of the Dry Pampas; and the second refer to the chert of the Cerro Largo Formation from the Pampa grasslands.

We analyze the composition of 81 lithic assemblages represented by flakes, cores and tools from the three Aeolian areas of central Argentina (CPD, WPD, and WPMD) (Figure 2). The goal was to amass a sample with lithic raw material data in order to construct comparative percentages. We use assemblages represented by 30 pieces or more. We assume that types of raw materials provide a useful comparative measure of lithic supply (sensu Bamforth 2009). Providing that the locations of geologic sources are known and that the probable source provenance of artifacts can be identified, simply plotting source locations provides a rough measure of the geographic space utilized (Seeman et al. 2020). We point out that the temporal aspects are not treated in detail in this work since a large part of the assemblages correspond to superficial assemblages, some of them possibly representing palimpsests, in which it is not possible to establish a precise temporal assignment. 


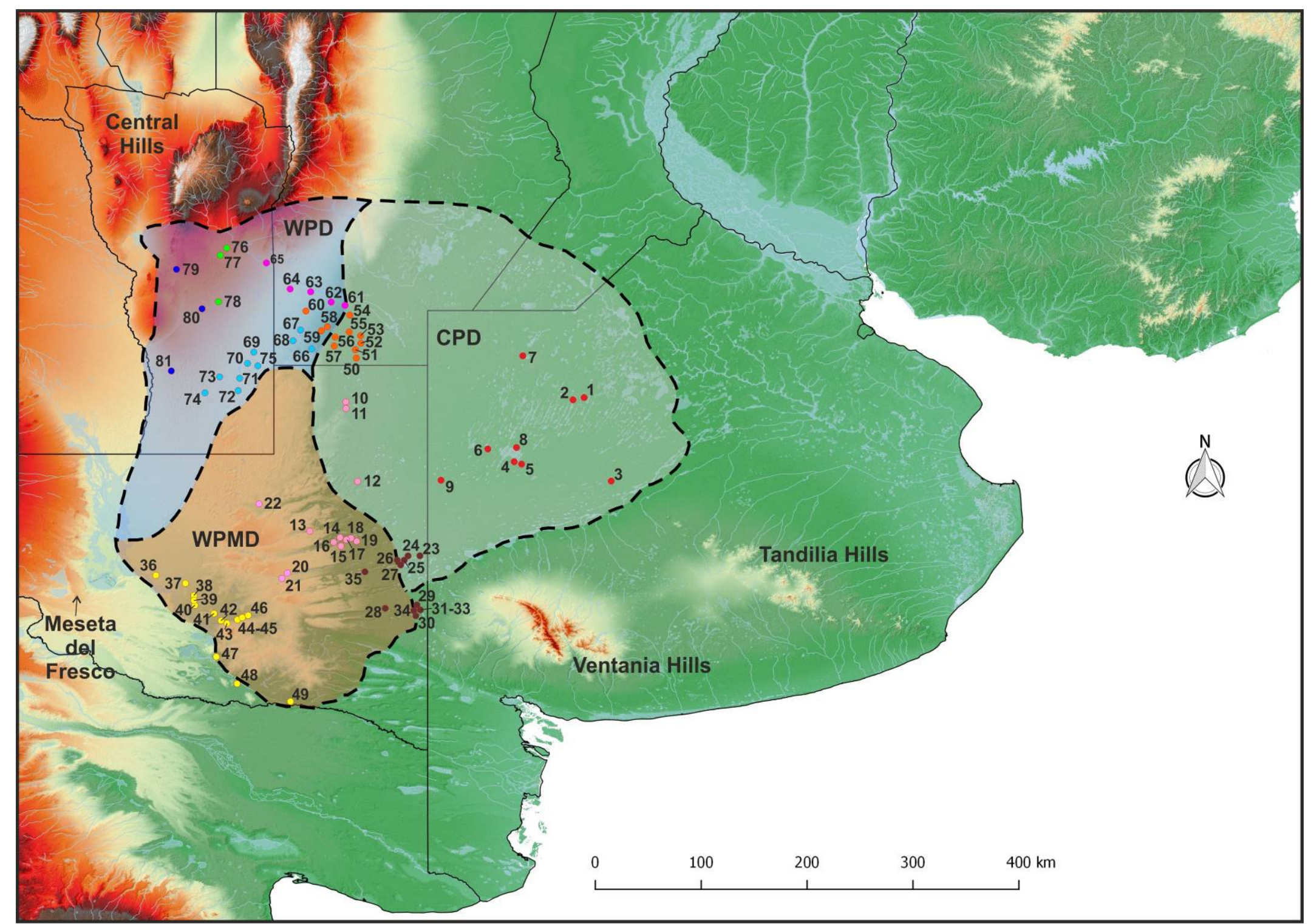

Figure 2. Locations of lithic assemblages plotted on the center-east of Argentina. Numbers are associated with the site names and assemblages are colored by area. 
Figure 2 (continued). Red, CPD from the Pampa grasslands; Pink, Center-east of the dry Pampas; Brown, Transverse valleys; Yellow, Salado-Curacó rivers and western dry Pampas; Orange, Eastern Pampa of the dry Pampas; Light blue, Xerophytic woodland and high structural; Violate, Quinto River; Green, Wet crossing; Blue, Dry crossing. Sites: 1) Laguna de los Pampas; 2) Laguna Giaccone; 3) Laguna Cabeza de Buey 2; 4) La Susana 1; 5) Laguna Chica; 6) Huencú Nazar; 7) Laguna Salalé; 8) Las Tunas Grandes; 9) Médano Santa Clara; 10) Laguna Chadilauquen; 11) Laguna Neicorehue; 12) Médanos de Peñín; 13) Loma Chapalcó; 14) Laguna Montoya; 15) Manantial Naicó; 16) Laguna Paisani; 17) Laguna de la Ruta; 18) Laguna del Medio; 19) Laguna del Fondo; 20) El Carancho 1; 21) Laguna Traru Lauquen; 22) Don Isidoro 2; 23) Médano de Castilla; 24) Médanos de Phagouapé; 25) Médanos de Alducín; 26) La Cascada; 27) Bajo de Atreucó; 28) Laguna La Tigra; 29) Laguna Guatraché; 30) Bajo de Marcelino; 31) Médano San Sixto; 32) Luis Otero; 33) Bajada La Minnesota; 34) El Carmel; 35) Chillhué; 36) El Encuentro; 37) Flor de Pago; 38) Médanos Lote 18; 39) Médanos Lote 24; 40) Los Sandovales; 41) El Castillo; 42) Laguna La Leona; 43) Médanos de Villa; 44) Chenque 1; 45) La Casona; 46) El Molino; 47) Manantial Curacó; 48) Tapera Moreira 1; 49) Confluencia 2; 50) La Silvia; 51) Laguna de Veliz; 52) Laguna de Tobarez; 53) Ruka May; 54) Los Vascos; 55) El Cristiano; 56) La Angelita; 57) Santa Blanca; 58) Laguna El 20; 59) La Eloisita; 60) San Alberto; 61) El Tigre; 62) El Charo; 63) Médano de Pacheco; 64) Santa Catalina; 65) Alto El Chañar; 66) Rali-có; 67) Borohué; 68) Tromencó; 69) Santa Paz/La Lonja; 70) Las Martinetas; 71) Médano El Bagual; 72) Médano de la Laguna El Bagual; 73) La Juanita; 74) Cochequinga; 75) Los Pedernales; 76) La Alborada; 77) Sayape; 78) San José de Escala; 79) Alto Pelado; 80) Loma de los Indios; 81) La Marona.

Subsequently, we calculate the frequency of lithic raw materials that come from the Tandilia Hills (Figure 1) and the closest distance of each assemblage to the acquisition areas because these tool-stones predominate in most CPD assemblages and in a few sites in the other two areas. Under the Tandilia sources denomination different types of rocks are grouped, mainly those stone that have very good quality for knapping as orthoquartzite from the Sierras Bayas Group, chert from the Cerro Largo Formation, and silicified dolomite from the Villa Mónica Formation (Messineo et al. 2019). We do not include those rocks used to manufacture grinding tools because there are not detailed studies on its probable area of provenance. We construct a fall-off curve (Renfrew 1977) which is based on the relationship between the frequency of an item and the distance to the source of supply. In this occasion, we use the extreme western sector of the Tandilia Hill as the point 0 (Figure $1 \mathrm{~N}^{0} 1 \mathrm{a}$ ). We carry out a statistical analysis (chi-squared test) to verify the correlation between both variables. Then, we calculate the average of the values by grouping assemblages into $50 \mathrm{~km}$ intervals from the Tandilia sources with the aims to construct a summary distance-decay model. This model allows us to examine the relative importance of the Tandilia sources as a function of distance from source zones and to infer possible foraging ranges.

\section{Results}

\subsection{Raw materials distribution}

Many of the raw material types observed in the assemblages could be attributed to specific, well-known geological sources. In the CPD assemblages, the most commonly observed raw material sources were orthoquartzite (65.6\%) from the Sierras Bayas Group and chert (25.1\%) from the Cerro Largo Formation, both from the Tandilia Hills (Figure 3). For each of the assemblages, values between $63.5 \%$ and $96 \%$ are observed for both Tandilia stones (Supplementary file 1). In very low frequencies were identified other stones from Ventania (rhyolite and methaquartzite), Salado and Colorado Rivers, Meseta del Fresco, and other outcrops in the xerophytic woodland of the Dry Pampas (silex and silicified limestone) (Supplementary file 1). In some sites of the CPD, which are located at a shorter distance from the Ventania outcrops (e.g., Laguna Chica, La Susana 1, and Huencú Nazar), very low percentages of rocks from these hills are recorded. 


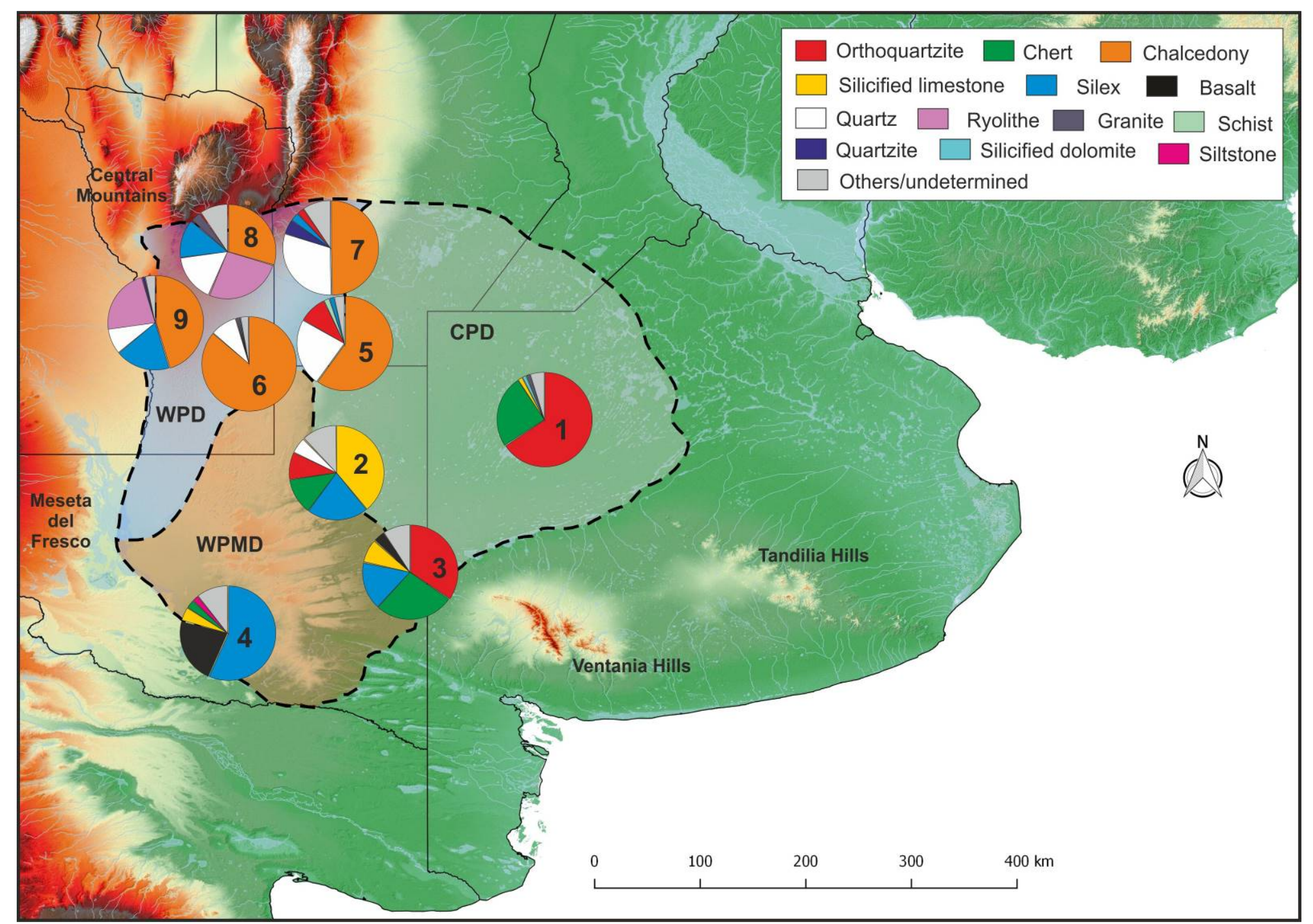

Figure 3. Frequency of the main lithic raw materials by areas. Numbers are associated with the areas: 1- CPD from the Pampa grasslands; 2- Center-east of the dry Pampas; 3Transverse valleys; 4- Salado-Curacó rivers and western dry Pampas; 5- Eastern Pampa of the dry Pampas; 6- Xerophytic woodland and high structural; 7- Quinto River; 8Wet crossing; 9- Dry crossing. 
In the WPMD there are three main areas, Center-east of the dry Pampas, Transverse valleys, and Salado-Curacó rivers and western dry Pampas (Figure 2), that have different proportions in terms of rock representation. In the former case, the general assemblage presents a predominance of silicified limestone (39.3\%), following by silex (16.4\%), chert (11.9\%), orthoquartzite (9.2\%), and quartz (5.5\%) (Figure 3). Some sites evidence a predominance of rocks from the xerophytic woodland of the Dry Pampas (e.g., silicified limestone, silex, and quartz); while in other assemblages (e.g., Manantial Naicó and Bajo del Medio) have high percentages of Tandilia rocks from the Pampa grasslands (Supplementary file 1) (Carrera Aizpitarte 2014: 229-265). In the Transverse valleys area, there is a predominance of orthoquartzite (34.8\%), chert (27.4\%), silex (16.1\%), silicified limestone (8.1\%), and basalt (4\%) (Figure 3). There are assemblages (e.g., Médanos de Castilla, La Cascada, and Bajo de Marcelino) with a predominance of Tandilia rocks from the east, other sites (e.g., Laguna La Tigra and Chillhué) with raw materials mostly from the west (silicified limestone and silex), and few cases (e.g., Médanos de Phagouapé and El Carmel) with similar proportions of both source of acquisitions (Supplementary file 1) (Berón et al. 2015). In the Salado-Curacó Rivers and western dry Pampas area predominates cobbles and pebbles from secondary river deposits of the Patagonian Shingle Formation, such as silex (56.8\%) and basalt (22.5\%) (Berón 2004: 129-150; Carrera Aizpitarte 2014: 111-150). Other stones were identified in very low frequencies, such as silicified limestone $(4.7 \%)$ and chert $(2.9 \%)$ (Supplementary file 1).

In the WPD assemblages, the best represented raw material is the chalcedony (between $29.6 \%$ and $86.3 \%$ ) followed by a group of other minority rocks, such as quartz, rhyolite, and silex (Supplementary file 1) (Heider 2015: 338-340). Considering the five areas defined by this author, the Wet and Dry crossings present percentages of predominant rocks from the Central Hills (e.g., chalcedony "type a", silex, and rhyolite) while in the three remaining areas (Eastern Pampa of the dry Pampas, Xerophytic woodland and high structural, and Quinto River) predominate the chalcedony "type b" (more than 50\%) (Figure 3) from the Loma de los Pedernales site (Figures 1 and 2). Meanwhile, among the minor raw materials, orthoquartzite from Tandilia sources were identified mainly in the Eastern Pampa of the dry Pampas area (Heider 2016a).

\subsection{Stone-tools from Tandilia}

Occurrences of long distance stones from Tandilia are the basis for describing lithic conveyance zones, which we suggest delimit geographically the foraging ranges of huntergatherer populations in the center of Argentina. In relation to this, Figure 4 presents the percentages of Tandilia stone-tools in each archaeological assemblages and their distance to the closet sector of the acquisition area of Tandilia Hill (Figure $1 \mathrm{~N}^{\mathrm{o}} 1 \mathrm{a}$; Supplementary file 1). The correlation between both variables through chi-squared analysis $(\chi 2=7376$ (94), $\mathrm{p}=$ 2.2e-16, $\varphi c=0.42$ ) indicates that as the sites move away from Tandilia, the frequency of these rocks decreases.

Most assemblages have a high percentage of Tandilia rocks up to $310 \mathrm{~km}$ away, with a percentage greater than $40 \%$ (Figure 4). These include all CPD assemblages from the Pampa grasslands, such as Laguna de los Pampas, La Susana 1, Laguna Cabeza de Buey 2, Huencú Nazar, and Laguna Chica, and most of the Transverse valleys sites (e.g., Bajo de Marcelino, Bajada La Minnesota, Médano de Castilla, La Cascada, Bajo de Atreucó, and Médanos de Alducín) in the WPMD (Figure 4; Supplementary file 1) (Berón et al. 2015; Carrera Aizpitarte 2014: 185-228).

Also, some of the sites located between 330 and $400 \mathrm{~km}$, most contexts of the Centereast of the dry Pampas area (Figure 2), have very variable frequency in terms of the presence 
of rocks from the Tandilia Hill. For instance, a group of assemblages has moderate frequencies, between 25 and 50\% (e.g., Manantial Naicó, Laguna de la Ruta, and Laguna del Medio), while other sites (e.g., Médanos de Peñín, Loma Chapalcó, Laguna Paisani, Laguna Montoya, and Laguna La Tigra) have low percentages, less than 25\% (Figure 4; Supplementary file 1) (Carrera Aizpitarte 2014: 229-265).

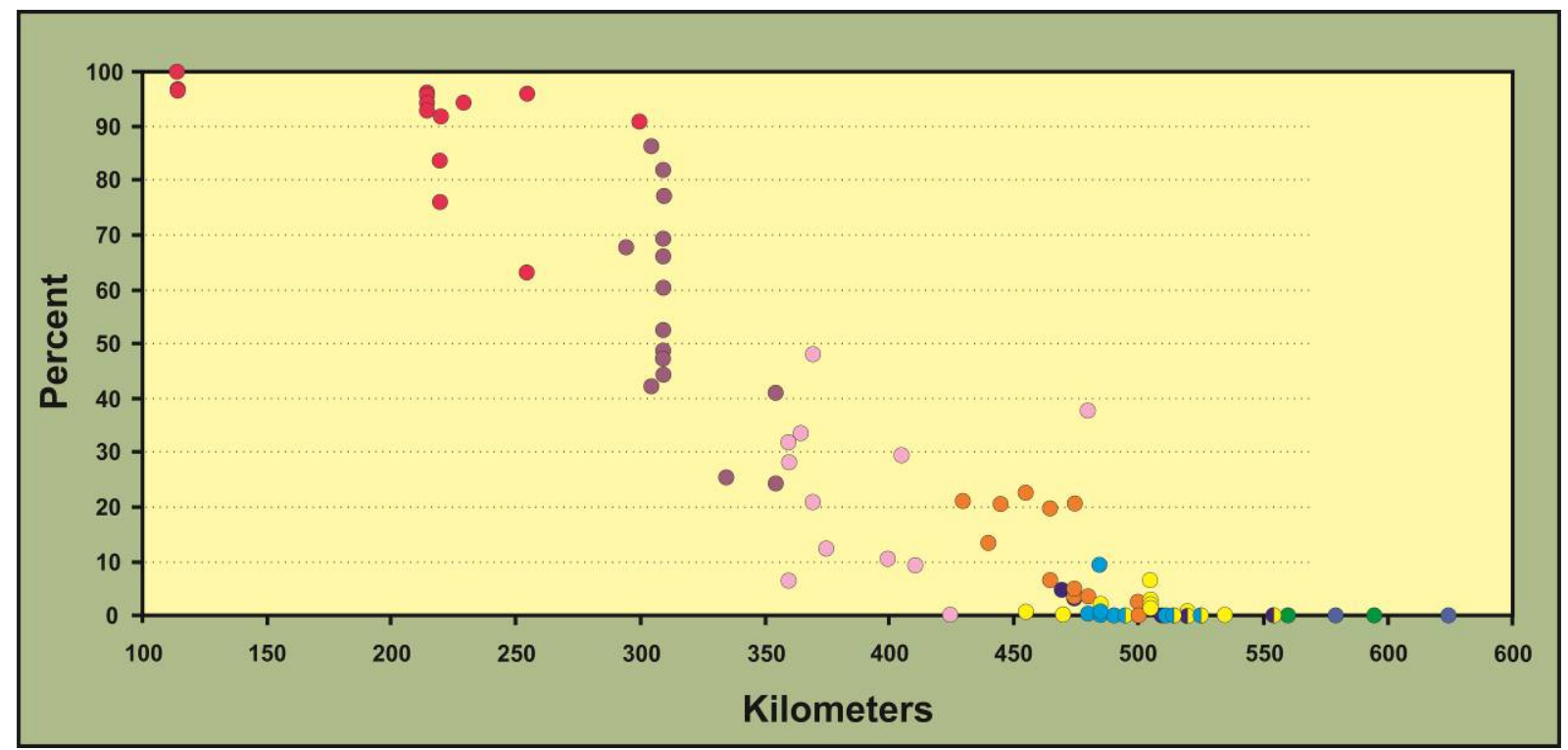

Figure 4. Correlation between frequency of lithic raw materials and distances to the Tandilia Hills.

On the other hand, the lithic assemblages from the Salado-Curacó Rivers and western dry Pampas, the Eastern Pampa of the dry Pampas, the Xerophytic woodland and high structural, and the Quinto River areas have low frequencies of stone tools from the Tandilia Hill (Figure 4) (Berón 2004: 255-261; Heider 2015: 340-342). For instance, a group of sites, located between 430 and $520 \mathrm{~km}$, have frequencies between 23 and 10\% (e.g., La Silvia, Laguna de Veliz, La Angelita, Santa Blanca, Laguna de Tobarez, El Tigre, El Charo and Borohué) (Figure 2), while other assemblages have very low percentages (e.g., Tapera Moreira, Chenque 1, La Casona, El Cristiano, San Alberto, and Rali-có). By last, the assemblages from the Wet and Dry crossing areas, located at distances greater than $520 \mathrm{~km}$, do not present rocks from the Tandilia Hill (Supplementary file 1) (Heider 2015: 340-342).

\section{Discussion}

While the three areas (CPD, WPD, and WPMD) are within the Aeolian system of central Argentina, in each of them there are own geomorphological characteristics (see Zárate \& Tripaldi 2012), offering different scenarios for the human groups that inhabited them. This generated particular relationships of the hunter-gatherers with the areas (e.g., selection of rocks, objectives of production, methods and techniques used for manufacturing) and with other neighboring areas (e.g., search and use of distant stones, tool and design circulation, and transmission of information and exchange).

In the CPD of the Pampa grasslands no primary and secondary outcrops have been found. The results obtained show that the predominant direction of movement of people and the circulation of stones went to and from the outcrops of the Tandilia sources (Figures 1 and 3) (Messineo et al. 2019). The distance to the mountains was not one of the main variables for the acquisition of these stones, because there are other closer outcrops (Ventania) that were exploited in smaller proportion. Instead, hunter-gatherer groups that occupied the CPD of the Pampa grasslands acquired mainly orthoquartzite and chert from the Tandilia Hills due to its 
excellent knapping quality (Bayón et al. 1999; Messineo \& Barros 2015). Certain tools (e.g., side-scrapers and end-scrapers), in addition to the rocks used for their manufacture, have typological similarities with those observed at sites located in the vicinity of the Tandilia Hills. Likewise, some caches of orthoquartzite have been found in the CPD of the Pampa grasslands (Madrazo 1972; Sanguinetti de Bórmida 1966; Scheifler 2019: 121-122; Scheifler et al. 2017), a behavior that generated reservoirs of stone in areas of the landscape devoid of this resource.

On contrary, in the WPMD and WPD there are primary and secondary outcrops of various rocks such as basalt, silex, quartz, rhyolite, chalcedony, and silicified limestone (Figure 1) (Berón 2004: 211-254; Carrera Aizpitarte 2014: 277-299; Heider 2015: 338-340; Heider \& Demichelis 2015). The sites present the exploitation of local and non-local rocks from the Meseta del Fresco, the Salado-Curacó Rivers, the Loma de los Pedernales site, and the Central Hills, among others (Figure 3). Some of the contexts that are located in the Transverse valleys and Eastern Pampa areas of the dry Pampas present variables percentages of Tandilia rocks, mainly orthoquartzite, which was used to manufacture side-scrapers, multipurpose tools and projectile points (Berón 2004: 255-261; Berón et al. 2015; Carrera Aizpitarte 2014: 375-378, 387-390; Heider 2015: 347-348). According to Berón et al. (2015), the presence of orthoquartzite tools allows to establish the existence of social interaction and/or the effective presence of social groups from the Pampa grasslands in the WPMD. On the other hand, Heider (2016b) proposed that the occurrence of this rock at sites in the Eastern Pampa areas of the Dry Pampas (430-500 km from Tandilia Hill), on the border between the WPD and CPD, constituted a possible ethnic boundary.

A summary fall-off curve for the relationship between stone from Tandilia and distance follows a regular pattern of decrease (Figure 5), that is, the frequency of occurrence of Tandilia rocks declines as the distance to their source of supply increases. There is a gap between 150 and $200 \mathrm{~km}$ that is linked to the absence of detailed published information about the probable provenance of lithic resources recovered in those assemblages. An average of $80 \%$ of the rocks from Tandilia is observed in those sites located between 250 and $300 \mathrm{~km}$, which allow us to infer the foraging range for human groups that occupied the CPD of the Pampa grasslands. After this distance, the curve documents a drop-off, particularly those assemblages located in the Transverse Valleys of the WPMD area (Figures 2 and 4). Between 300 and $350 \mathrm{~km}$ of distance from Tandilia, we observed an average of $60 \%$ of stone tools from this source. In addition to the high frequency of these rocks in the CPD of the Pampa grasslands and in the Transverse Valleys areas, a great diversity of tools, cores, and various stages of the reduction sequences in orthoquartzite and chert from Tandilia are identified in numerous assemblages (Berón et al. 2015; Messineo et al. 2019). This spatial analysis indicates that the cumulative distance of $\sim 350 \mathrm{~km}$ to the Tandilia source probably represent the threshold of direct procurement to these stones during the logistic and/or in the course of the hunter-gatherer's annual mobility (Binford 1979). That is, the territories occupied by hunter-gatherer groups, who could travel within that landscape without restrictions, visit other bands, and use the resources found there.

Tandilia stone-tools (orthoquartzite of the Sierras Bayas Group and chert of the Cerro Largo Formation) seem to systematically supply a relatively wide area of the Pampa grasslands, through varied processes (Bayón et al. 2006; Barros et al. 2015; Martínez \& Mackie 2003/2004; Messineo \& Barros 2015). However, they arrive at very low frequencies over great distances, such as in the WPD (Heider 2016b) and the WPMD, mainly in the Center-east of the dry Pampas and the Salado-Curacó rivers areas (Berón 2004: 255-261; Carrera Aizpitarte 2014: 375-378, 387-390). These data show that orthoquartzite and chert from Tandilia Hill were conveyed from the sources within a zone measuring over $550 \mathrm{~km}$ in a southeast-northwest direction in the WPD and $450 \mathrm{~km}$ in an east-west direction in the WPWD 
(Figure 2). Within this distribution, some contexts represent outliers with abundant orthoquartzite and chert from Tandilia (Figure 3) that exceeds the expected values for their location.

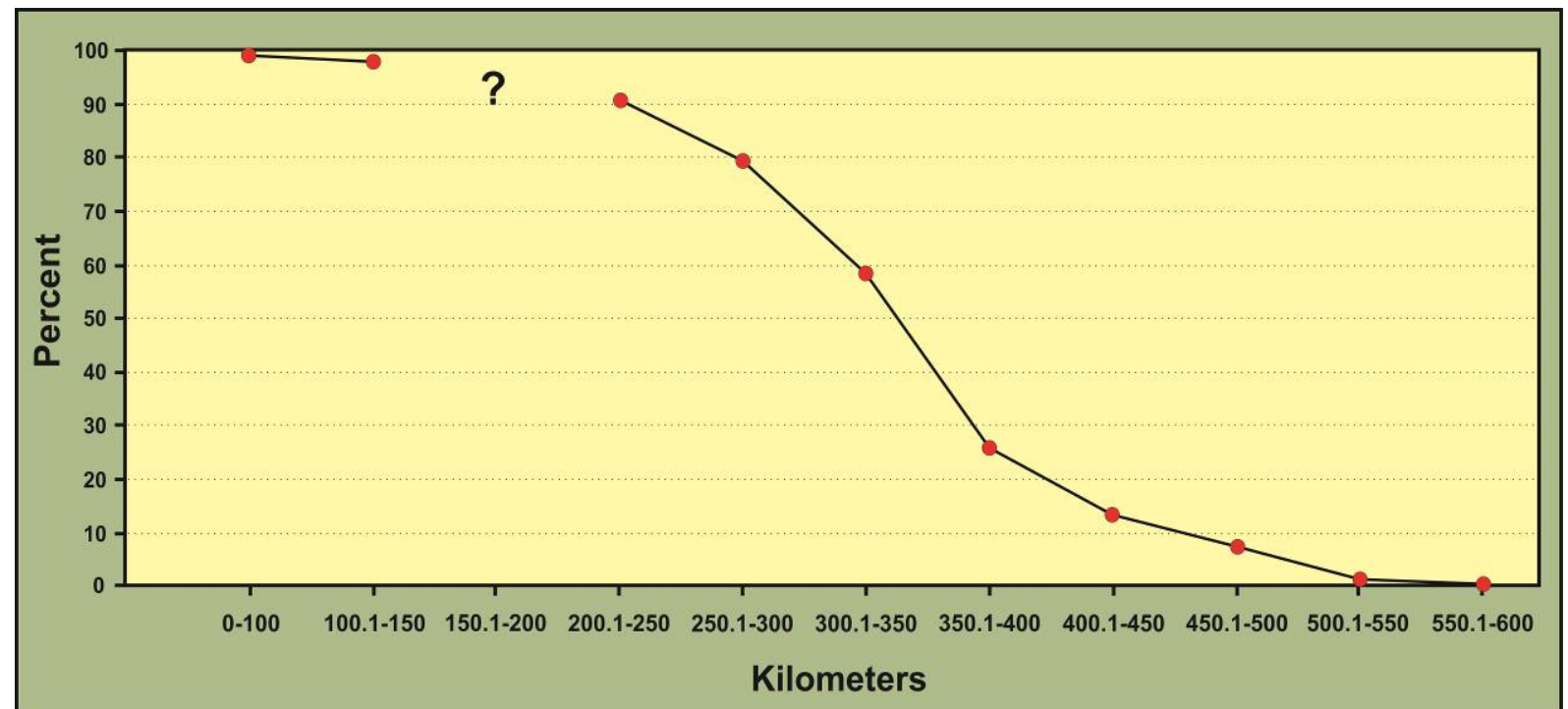

Figure 5. Percentage fall-off of Tandilia sources with distances into $50 \mathrm{~km}$ intervals. The gap (?) is linked to the absence of detailed published information about the probable provenance of lithic resources recovered in those assemblages.

A fringe between 350 and $400 \mathrm{~km}$ could be interpreted as a landscape with flexible territorial boundary occupied and visited by several human groups (see Heider 2016b). The distribution of Tandilia rocks beyond this radius involved other provisioning strategies such as indirect procurement through the interaction between hunter-gatherer groups that occupy different territories. This is also supported by the presence in these sites of high percentages of rocks from the western Pampas (silicified limestone), the rivers that cut the WPMD (basalt and silex) and the Central Hills (quartz, chalcedony, and rhyolites; Figures 1 and 3; Supplementary file 1). In this situation of indirect acquisition, it is possible recognize in the WPD and WPMD assemblages with a low frequency of Tandilia stone artifacts (usually orthoquartzite and chert curated tools; sensu Binford 1979), as well as the use of certain kinds of tools, such as side-scraper, end-scrapers, and projectile points, characteristic from the Pampa grasslands (Berón 2004: 257-258; Berón et al., 2015; Heider 2015: 347-348).

For example, the exchange of lithic tools through social interaction can be traced through the identification of different types of projectile points. First, the predominant projectile points in the CPD assemblages are medium and small sized triangular stemless with straight bases and, to a lesser extent, slightly convex. These points were predominantly manufactured with rocks from the Tandilia Hill such as orthoquartzite and chert (Figure 6A-D). In addition, some projectile points with similar technological characteristics and made with rocks from Ventania (rhyolite) and the xerophytic woodland of the Dry Pampas (basalt and silicified limestone) are found in the CPD (Figure 6E-G), suggesting a shared common technological knowledge among hunter-gatherer groups. Secondly, some points, also found in the CPD, were not only made with rocks from the western Pampas but also have different technological features (Figure 6H). Lastly, in the Eastern Pampa of the dry Pampas and the xerophytic woodland areas there are projectile points made with orthoquartzite and chert from the Tandilia Hill (Figure 6I-L). These interactions generated the movement of rocks and tools over great distances, as well as their replication on other raw materials available in each area (see Berón 2004: 257-258; Berón et al., 2015; Heider 2016b). 

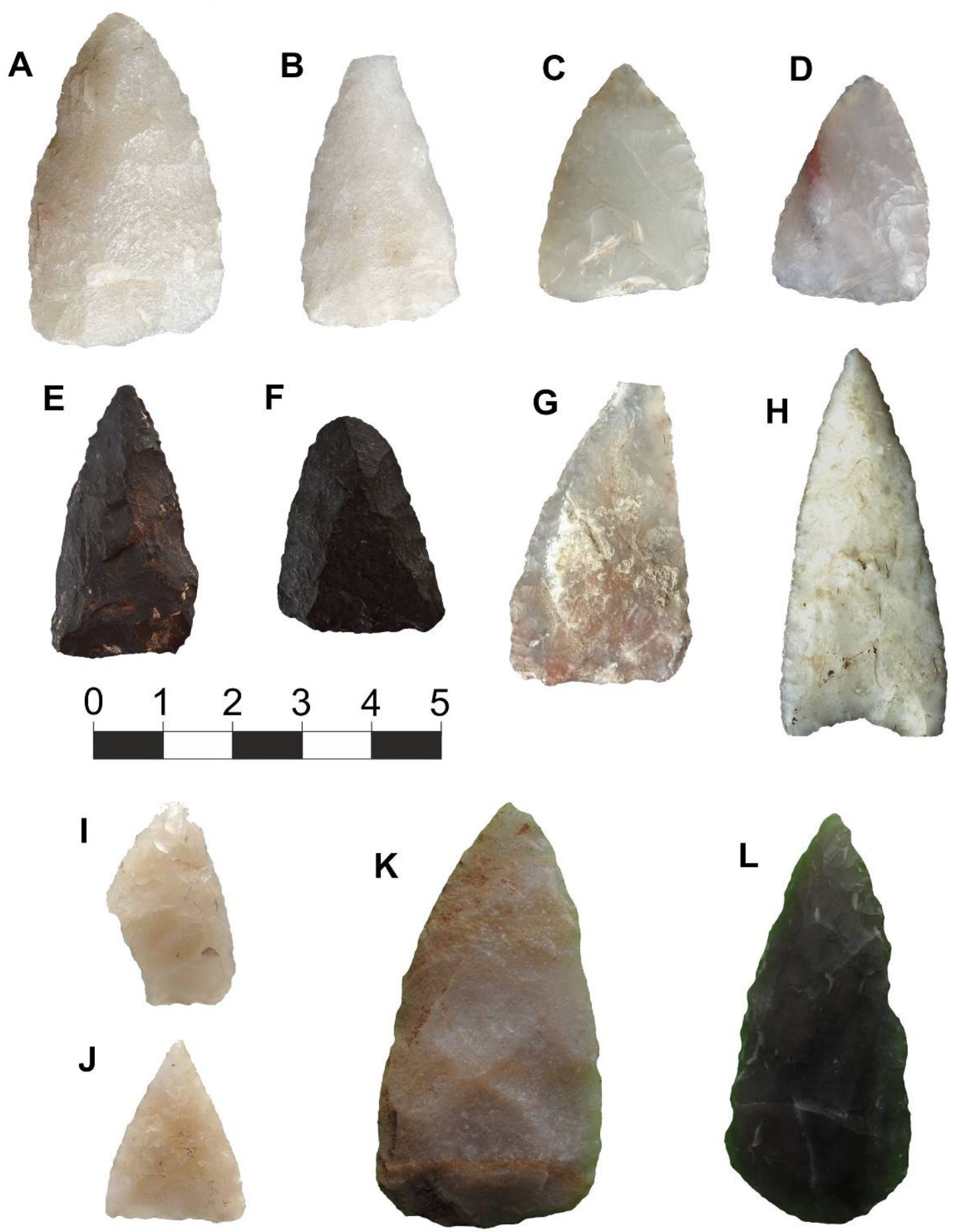

Figure 6. Projectile points found in the Aeolian System of central Argentina. Upper and middle files: Projectile points found in the CPD: A-B- Orthoquartzite from Tandilia Hill (Laguna Chica site); C-D- Chert from Tandilia Hill (Laguna Chica site); E- Rhyolite from Ventania Hill (La Susana 1 site); F- Basalt from the Atlantic coast or the xerophytic woodland (Laguna Chica site); G- Silicified limestone from the xerophytic woodland (Laguna Chica site); H- Chalcedony from the xerophytic woodland (Laguna Chica site). Lower file: Projectile points found in the WPMD and WPD areas: I- Chert from Tandilia Hill (Manantial Naicó site); J- Orthoquartzite from Tandilia Hill (Parque Luro site) (Photos courtesy of Manuel Carrera Aizpitarte); K- Ortoquartize from Tandilia Hill (La Angelita site), L- Chert from Tandilia Hill (La Angelita site) (Photos courtesy of Guillermo Heider).

\section{Conclusion}

The study carried out here allowed us to establish that the modes of raw material acquisition and circulation varied in the three areas of the Aeolian System of the center of 
Argentina. The frequency of lithic raw materials in each area is consistent with the lithic distribution in the landscape, indicating that the human groups preferably used the lithic raw materials that were within their foraging range of their territory. The characteristics of each area produced that the human groups that inhabited them developed different modes of exploitation of the rocks. In the CPD of the Pampa grasslands, most rocks were obtained through direct procurement (individual supply) from the Tandilia Hill. The sites essentially formed part of a wider mobility circuit that connected different groups from diverse environments since the territories were flexible. The presence in the WPD and WPMD of orthoquartzite and chert tools made with Tandilia rocks and the identification of projectile points in the CPD manufactured with rocks from the xerophytic woodland of the Dry Pampas indicate social interaction at the regional scale between hunter-gatherer groups who occupied the Aeolian System of central Argentina.

\section{Acknowledgements}

To the editors of the volume (Otis Crandell, Xavier Mangado, and Vincent Delvigne) for the invitation to participate with our contribution. We are grateful to Manuel Carrera Aizpitarte and Guillermo Heider for providing us the photos for Figure 6. We also thank Florencia Santos Valero and two anonymous reviewers for the suggestions and corrections made in the manuscript. This research is supported by the National Geographic Society (Grants \#9773-15 and \#NGS-50543R-18), the Consejo Nacional de Investigaciones Científicas y Técnicas (PIP N ${ }^{\circ}$ 0414), and the Agencia Nacional de Promoción Científica y Tecnológica (PICT 2014-2070 and PICT 2018-02154). This article is a production of the UE INCUAPA-CONICET, Facultad de Ciencias Sociales (UNICEN).

\section{Data accessibility statement}

The authors confirm that the data of this study are available within the text and in the supplementary file.

\section{List of supplementary files}

Supplementary file 1

"MESSINEO_BARROS - supplementary file 1 - Supplementary file 1.pdf"

Quantity and frequency of lithic raw materials by site and area.

\section{References}

Andrefsky, W. 1994, Raw-material availability and the organization of the technology. American Antiquity, 59: 21-34. doi:10.2307/3085499

Bamforth, D.B. 1986, Technological efficiency and tool curation. American Antiquity, 51: 3850. doi:10.2307/280392

Bamforth, D.B. 1990, Settlement, raw material and lithic procurement in the Central Mojave Desert. Journal of Anthropological Archaeology, 9: 70-104. doi:10.1016/02784165(90)90006-Y

Bamforth, D.B. 2009, Projectile points, people, and plains Paleoindian perambulations. Journal of Anthropological Archaeology, 28(2): 142-157. doi:10.1016/j.jaa.2009.01.002

Barros, M.P., Messineo, P.G. \& Colantonio, M.J. 2015, Chert quarries and workshops in the Humid Pampa sub-region: New contributions on exploitation techniques and circulation 
through study of chaînes operatoires. Quaternary International, 375: 99-112. doi:10.1016/j.quaint.2014.07.017

Bayón, C., Flegenheimer, N., Valente, M. \& Pupio, A. 1999, Dime cómo eres y te diré de dónde vienes: La procedencia de rocas cuarcíticas en la región pampeana. Relaciones de la Sociedad Argentina de Antropología, 24: 187-235. (in Spanish) (“Tell me how you are and I will tell you where you come from: The origin of quartzite rocks in the Pampas region”)

Bayón, C., Flegenheimer, N. \& Pupio, A. 2006, Planes sociales en el abastecimiento y traslado de roca en la Pampa Bonaerense en el Holoceno temprano y tardío. Relaciones de la Sociedad Argentina de Antropología, 31: 19-45. (in Spanish) ("Social plans in the procurement and move of rock in the Pampas of Buenos Aires in the early and late Holocene”)

Berón, M.A. 2004, Dinámica poblacional y estrategias de subsistencia de poblaciones prehispánicas de la cuenca Atuel-Salado-Chadileuvú-Curacó, Unpublished PhD Thesis, Facultad de Filosofía y Letras, Universidad de Buenos Aires. Buenos Aires, Buenos Aires, 536 p. (in Spanish) ("Population dynamic and subsistence strategies of prehispanic populations from the Atuel-Salado-Chadileuvú-Curacó Basin”)

Berón, M.A. 2006, Base regional de recursos minerales en el occidente pampeano. Procedencia y estrategias de aprovisionamiento. Relaciones de la Sociedad Argentina de Antropología, 31: 47-88. (in Spanish) ("Regional base of mineral resources in western Pampas. Provenance and sourcing strategies”)

Berón M.A., Carrera Aizpitarte, M. \& Páez, F. 2015, Arqueología en el área de Valles Transversales (provincia de La Pampa, Argentina). Caracterización y tendencias de los conjuntos arqueológicos. Implicancias sociales en la construcción del paisaje. Relaciones de la Sociedad Argentina de Antropología, 40(2): 549-587. (in Spanish) (“Archeology in the Transversal Valleys area (La Pampa province, Argentina). Characterization and tendencies of the archaeological assemblages. Social implications in landscape construction”)

Binford, L.R. 1979, Organization and formation processes: Looking at curated technologies. Journal of Anthropological Research, 35: 255-273. doi:10.1086/jar.35.3.3629902

Bonnat, G.F. 2016, Análisis de la organización de la tecnología lítica de los grupos cazadores-recolectores tempranos del área de Tandilia Oriental, Buenos Aires. Sociedad Argentina de Antropología, Buenos Aires, 269 p. (in Spanish) (“Analysis of the lithic technology organization of early hunter-gatherer groups of the Eastern Tandilia area, Buenos Aires”)

Bonomo, M. \& Prates, L. 2014, La explotación de depósitos secundarios de rodados en el curso medio del Río Negro y el litoral Marítimo Pampeano. In: Artefactos Líticos, Movilidad y Funcionalidad de Sitios en Sudamérica. Problemas y Perspectivas (Escola, P. \& Hocsman, S., Eds.) BAR International Series Vol. 2628, Oxford, p. 77-92. (in Spanish) ("The exploitation of secondary pebble deposits in the middle course of the Río Negro and the Pampean Maritime coast”)

Carrera Aizpitarte, M. 2014, Estudio de las estrategias de aprovisionamiento lítico en las áreas Curacó, Bajos sin Salida, Valles Transversales y Centro-este (provincia de La Pampa, Argentina), Unpublished PhD Thesis, Facultad de Ciencias Sociales, Universidad Nacional del Centro de la Provincia de Buenos Aires, Olavarría, 471 p. (in Spanish) 
("Study of the lithic procurement strategies in Curacó, Bajos sin Salida, Valles Transversales, and Centro-Este areas, La Pampa province, Argentina”)

Carrera Aizpitarte, M.P. \& Berón, M.A. 2020, Explotación de recursos líticos en dos canteras prehispánicas de la provincia de La Pampa (Argentina): Meseta del Fresco y Manto Tehuelche. Estudios Atacameños, 66: 7-34. (in Spanish) ("Exploitation of lithic resources from two prehispanic quarries of La Pampa province (Argentina): Meseta del Fresco and Manto Tehuelche”) doi:10.22199/issn.0718-1043-2020-0051

Carrera Aizpitarte, M.P., Berón, M.A. \& Blasi, A. 2015, Study of siliceous outcrops of Meseta del Fresco, La Pampa, Argentina. Quaternary International, 375: 27-43. doi:10.1016/j.quaint.2014.11.061

Catella, L. 2014, Movilidad y utilización del ambiente en poblaciones cazadoras recolectoras del sur de la Región Pampeana: la cuenca del Arroyo Chasicó como caso de estudio, Unpublished PhD Thesis, Facultad de Ciencias Naturales y Museo, Universidad Nacional de La Plata, La Plata, 406 p. (in Spanish) ("Mobility and environment use in hunter-gatherer populations of the southern Pampas Region: The Chasicó Creek basin as Case Study”)

Catella, L., Manassero, M., Moirano, J. \& Oliva. F. 2013, Nuevos aportes al estudio del aprovisionamiento de cuarcita en la Región Pampeana, Argentina. Cuadernos del Instituto Nacional de Antropología y Pensamiento Latinoamericano, 1(2): 200-215. (in Spanish) ("New contributions to the study of quartzite acquisition in the Pampean Region, Argentina”) URI: http://hdl.handle.net/11336/24500

Charlin, J. 2002, Aprovisionamiento de materias primas líticas en el N.O. de la provincia de la Pampa a fines del Siglo XIX. In: Del Mar a los Salitrales. 10.000 años de Historia pampeana en el umbral del Tercer Milenio (Mazzanti, D., Berón, M. \& Oliva, F., Eds.), Laboratorio de Arqueología, Facultad de Humanidades, Universidad Nacional de Mar del Plata, Mar del Plata, p. 205-218. (in Spanish) ("Raw material procurement in the Northwest of La Pampa province at the end of the $19^{\text {th }}$ century")

Colombo, M. 2011, Modalidades de abastecimiento de rocas entre los cazadores y recolectores pampeanos. Intersecciones en Antropología, 12: 231-243. (in Spanish) ("Modalities of rocks procurement between the pampean hunters and gatherers")

Féblot-Augustins, J. 1997, La circulation des matières premières au Paléolithique, vol. 2, Études et recherches archéologiques de l'Université de Liège (ERAUL) Vol. 75, Université de Liège, Liège, 275 p. (in French) ("The circulation of raw material in the Paleolithic")

Flegenheimer, N., Kain, C., Zárate, M. \& Barna, A. 1996, Aprovisionamiento de cuarcitas en Tandilia, las canteras de Arroyo Diamante. Arqueología, 6: 117-141. (in Spanish) ("Quartzite procurement in Tandilia, the quarries of the Diamante creek")

Heider, G. 2015, Los Pueblos Originarios en el Norte de Pampa Seca. Una mirada arqueológica a los cazadores recolectores del Sur de las provincias de Córdoba y San Luis, Argentina, Unpublished PhD Thesis, Facultad de Filosofía y Humanidades, Universidad Nacional de Córdoba, Córdoba, 441 p. (in Spanish) ("Native peoples from the North of the Dry Pampas. An archaeological view of hunter-gatherers that inhabited the South of Córdoba and San Luis provinces, Argentina”) 
Heider, G. 2016a. La gestión de recursos líticos en el Norte de Pampa Seca. Relaciones de la Sociedad Argentina de Antropología, 41(2): 375-396. (in Spanish) ("The management of lithic resources in the North of Pampa Seca")

Heider, G. 2016b. Un aporte a la discusión sobre las ortocuarcitas del grupo Sierras Bayas: ¿el sur de Córdoba como una frontera? Intersecciones en Antropología, 17: 303-313. (in Spanish) ("A contribution to the discussion about the orthoquarzites of the Sierras Bayas group: The south of Córdoba as a border?”)

Heider, G. \& Demichelis, A. 2015, Loma de los Pedernales, a local raw material source in the North of Pampa Seca, Argentina. Quaternary International, 375: 3-12. doi:10.1016/j.quaint.2015.02.059

Hughes, R.E. 2011, Sources of inspiration for studies of prehistoric resource acquisition and material conveyance in California and the Great Basin. In: Perspectives on Prehistoric Trade and Exchange in California and the Great Basin (Hughes, R.E., Ed.), University of Utah Press, Salt Lake City, Utah, p. 1-21.

Khun, S. 1995, Mousterian Lithic Technology. An Ecological Perspective. Princeton University Press, Princeton, 224 p. doi:10.1515/9781400864034

Kelly, R.L. 2011, Obsidian in the Carson Desert: Mobility or trade? In: Perspectives on Prehistoric Trade and Exchange in California and the Great Basin (Hughes, R.E., Ed.), University of Utah Press, Salt Lake City, Utah, p. 189-200.

Madrazo, G. 1972, Arqueología de Lobería y Salliqueló (Pcia. de Buenos Aires). Etnia, 15:118. (in Spanish) (Archeology of Lobería and Salliqueló (Province of Buenos Aires)

Malagnino, E. 1989, Paleoformas de origen eólico y sus relaciones con los modelos de inundación de la Provincia de Buenos Aires. In: Actas del IV Simposio de Percepción Remota, IX Reunión Plenaria SELPER. Tomo II, Sociedad Latinoamericana en Percepción Remota y Sistemas de Información Espacial (SELPER), San Carlos de Bariloche: p. 611-620. (in Spanish) ("Paleoforms of aeolian origin and its relations with the flood models of the Province of Buenos Aires")

Mangado, J. 2006, El aprovisionamiento en materias primas líticas: hacia una caracterización paleocultural de los comportamientos paleoeconómicos. Trabajos de Prehistoria, 63(2): 79-91. (in Spanish) (Provisioning in lithic raw materials: Towards a paleocultural characterization of paleoeconomic behaviors). doi:10.3989/tp.2006.v63.i2.18

Martínez, G.A. \& Mackie, Q. 2003/2004, Late Holocene human occupation of the Quequén River valley bottom: Settlement systems and an example of a built environment in the Argentine Pampas. Before Farming: The Archaeology and Anthropology of HunterGatherers, 1: 178-202.

Martínez, O.A., Rabassa, J. \& Coronato, A. 2009, Charles Darwin and the first scientific observations on the Patagonian Shingle Formation (Rodados Patagónicos). Revista de la Asociación Geológica Argentina, 64(1): 90-100.

URI: http://hdl.handle.net/11336/135176

Meltzer, D.J. 1989, Was stone exchanged among Eastern North American Paleoindians? In: Eastern Paleoindian Lithic Resource Use (Ellis, C. \& Lothrop, L., Eds.), Westview Press, Boulder, p. 11-39.

Messineo, P.G. \& Barros, M.P. 2015, Lithic raw materials and modes of exploitation in quarries and workshops from the center of the Pampean grassland of Argentina. Lithic Technology, 40(1): 3-20. doi:10.1179/2051618514Y.0000000007 
Messineo, P.G., Barros, M.P., Pal, N. \& Scheifler, N.A. 2019, Transporting rocks to an empty environment of lithic raw materials. The case of the Central Pampean Dunefield (Argentina). Journal of Archaeological Science Report, 25: 433-446. doi:10.1016/j.jasrep.2019.05.012

Oliva, F. \& Moirano, J. 1997, Primer informe sobre aprovisionamiento primario de riolita en Sierra de La Ventana. In: Arqueología Pampeana en la Década de los 90 (Berón, M. \& Politis, G.G., Eds.), Museo de Historia Natural de San Rafael, San Rafael, p. 137-146. (in Spanish) ("First report about primary procurement of rhyolite at Sierra de la Ventana")

Oliva, F., Ávila, J.D., Ayuso, M., Catella, L. \& Gallego, M. 2006, Investigaciones arqueológicas en la cuenca del arroyo Chasicó y llanura adyacente, Sudoeste de la Provincia de Buenos Aires. Comechingonia, Revista de Arqueología, 9: 123-139. (in Spanish) (“Archaeological research in the upper basin of Chasicó creek and adjacent plain, southwest of the Province of Buenos Aires). doi:10.37603/2250.7728.v9.n1.27619

Pallo, M.C. \& Borrero, L.A. 2015, ¿Intercambio o movilidad?: una evaluación sobre el uso de escalas de análisis espaciales y curvas de declinación en Patagonia centro-meridional (Argentina). Latin American Antiquity, 26: 287-303. (in Spanish) (“¿Exchange or mobility?: An evaluation of the use of spatial analysis scales and declination curves in central-southern Patagonia (Argentina) doi:10.7183/1045-6635.26.3.287

Renfrew, C. 1977, Alternative models for exchange and spatial distribution. In: Exchange Systems in Prehistory (Earle, T. \& Ericson, J., Eds.). Academic Press, New York, p. 7190. doi:10.1016/8978-0-12-227650-7.50010-9

Sanguinetti de Bórmida, A. 1966, Las industrias de Trenque Lauquen (Provincia de Buenos Aires). Acta Prehistórica, 5-7: 72-94. (in Spanish) (“The Trenque Lauquen industries (Province of Buenos Aires”)

Santos Valero, F. 2015, Contribuciones al conocimiento de la tecnología lítica en el valle inferior del Río Colorado: Sitio El Puma 3 (provincia de Buenos Aires). Intersecciones en Antropología, 16: 237-251. (in Spanish) ("Contributions to the knowledge of the lithic technology at the lower valley of the Colorado River: El Puma 3 site, province of Buenos Aires”)

Scheifler, N.A. 2019, Ecología y subsistencia de los cazadores-recolectores en el Campo de Dunas del Centro Pampeano. Sociedad Argentina de Antropología, Buenos Aires, 272 p. (in Spanish) (Ecology and Subsistence of hunters and gatherers in the Central Pampean Dunefields)

Scheifler, N.A., Messineo, P.G. \& Antiñir, A., 2017, Cazadores-recolectores en el sistema lagunar Hinojo-Las Tunas (región pampeana, área Oeste) durante la transición Holoceno temprano-medio y tardío. Primeros resultados de las investigaciones arqueológicas. Comechingonia, Revista de Arqueología, 21(1): 287-314. (in Spanish) (Hunters-gatherers in the Hinojo-Las Tunas lagoon system (Pampas, West area) during the early-middle and late Holocene transition. First results of archaeological investigations”) doi:10.37603/2250.7728.v21.n1.19396

Seeman, M.F., Colucci, A.N. \& Fulk, C. 2020, Hunter-gatherer mobility and versatility: A consideration of long-term lithic supply in the Midwest. American Antiquity, 85(1): 113-131. doi:10.1017/aaq.2019.72 
Smith, G.M., LaValley, S.J. \& Wiggins, K.M. 2012, Late Holocene lithic procurement strategies in the northwestern Great Basin: The view from Paiute Creek Shelter, Nevada. North American Archaeology, 33(4): 399-427. doi:10.2190/NA.33.4.b

Zárate, M. \& Tripaldi, A. 2012, The aeolian system of central Argentina. Aeolian Research, 3: 401-417. doi:10.1016/j.aeolia.2011.08.002 